\title{
Determinants of exclusive breastfeeding practices among mothers in azezo district, northwest Ethiopia
}

\author{
Mulusew Andualem Asemahagn
}

\begin{abstract}
Background: Exclusive breastfeeding (EBF) is a very important, long lasting and cost effective intervention to help reduce the morbidity and mortality of infants. However, a large proportion of infants are not exclusively breastfed as recommended by the World Health Organization. The study aim was to assess the exclusive breastfeeding practices and identify determinants among mothers in Azezo District, Ethiopia.

Methods: A community based cross-sectional study was conducted among 346 mothers with infants aged between 0-6 months. Data were collected using a pretested, interviewer administered questionnaire. Descriptive statistics and logistic regression analysis were used to describe the study objectives and identify the determinants of EBF in the previous $24 \mathrm{~h}$. Associations between the study and outcome variables were described using odds ratios and $95 \%$ confidence intervals (Cl).

Results: Any breastfeeding and exclusive breastfeeding in the previous $24 \mathrm{~h}$ were 99 and $79 \%$, respectively. The mean number of exclusive breastfeeds in the $24 \mathrm{~h}$ period was 6.5. Exclusive breastfeeding rates were highest among mothers aged $\geq 30$ years (Adjusted odds ratio [AOR] 1.75; $95 \% \mathrm{Cl} 1.14,3.42$ ). Infants whose mothers were unemployed were more likely to be exclusively breastfed than infants whose mothers were employed (AOR 1.62; $95 \% \mathrm{Cl} 1.03,2.95$ ). Mothers earning $\leq 1000$ birr (US \$47.62) monthly were $77 \%$ less likely to practice EBF (AOR 0.23; $95 \% \mathrm{Cl} 0.13,0.44)$. Mothers who delivered at the healthcare facility practised more exclusive breastfeeding than those who delivered at home (AOR 2.18; $95 \% \mathrm{Cl} 1.22$, 4.35). Mothers who received antenatal and postnatal care had better rates of EBF (AOR 2.24; $95 \% \mathrm{Cl}$ 1.18, 5.76 and AOR 1.62; $95 \% \mathrm{Cl} 1.09,3.21$ ) and mothers not practicing prelacteal feeding were more likely to exclusively breastfeed compared with mothers practicing prelacteal feeding (AOR 2.16; $95 \%$ Cl 1.16, 4.06).
\end{abstract}

Conclusions: Any breastfeeding and exclusive breastfeeding rates in the previous $24 \mathrm{~h}$ are relatively high in the study area compared with previous studies. Maternal factors (age, education, income, employment, antenatal care, prelacteal feeding), infants' age, delivery place and information access were independent predictors to EBF in previous $24 \mathrm{~h}$. Improving the mother's knowledge, income, information access, nutritional counselling, quality of antenatal and postnatal care service, place of delivery and avoiding prelacteal feeding practices are important to improving the exclusive breastfeeding rate in the previous $24 \mathrm{~h}$.

Keywords: Infants, Exclusive breastfeeding, Factors, Azezo District, Ethiopia 


\section{Background}

The World Health Organization (WHO) recommends the practice of exclusive breastfeeding (EBF) for the first six months in addition to its continuation with the addition of supplementary foods, for 2 years or more [1]. Exclusive breastfeeding is the practice of feeding on infants only breast milk for the first six months $[1,2]$. It is the most cost effective intervention to reduce infant morbidity and mortality worldwide [2-4]. Exclusive breastfeeding is crucial since human milk contains nutrients, living cells and defensive factors which enable infants to have a better immunity, physical and mental development $[5,6]$.

However, more than $85 \%$ of mothers worldwide did not follow WHO recommendation and only $35 \%$ of infants younger than four months was exclusively breastfed [7]. Evidence shows that the majority of mothers started to EBF their infants at birth and the rate declined greatly about two or more months $[1,4,6,7]$. Almost half of the 10 million deaths of children younger than 5 years old every year are direct or indirect consequences of malnutrition. Many of those deaths are associated with inappropriate breastfeeding practices $[7,8]$.

A cross-sectional study conducted in 2010 from Southern Brazil [9] showed a $72.5 \%$ overall breastfeeding rate, and 43.7 and 53.9 \% EBF among infants younger than six and four months of age, respectively. Based on another study from Al-Hassa, Saudi Arabia [10], only $24.4 \%$ infants were exclusively breastfed at the age of six months. In India, the 462 mothers in this study did EBF their infants at birth, and the rate was $97.0 \%$ at 3 months and $62.0 \%$ up to six months of age [11]. Similarly, evidence from Canada indicated an overall exclusive breastfeeding rate of $90.3 \%$ at birth and $13.8 \%$ up to six months of age [12].

Despite several interventions, the rate of EBF in the previous $24 \mathrm{~h}$ continues to be inadequate in developing countries [8, 13-17]. Based on a study from rural Africa [14], EBF prevalence was varied among HIV and non HIV mothers. Exclusive breastfeeding rates at three and five months were 83.1 and $76.5 \%$, respectively among HIV negative women and 72.5 and $66.7 \%$, respectively among HIV positive women.

Evidence from Ghana [14] revealed that 99.7 and $51.6 \%$ of mothers practiced EBF and non-exclusive breastfeeding. Other studies show that less than half (19 and $48 \%$ ) of women exclusively breastfed their infants up to the ages of four months in Tanzania and Uganda, respectively [15]. Another study from Uganda [16] also revealed that $99.0 \%$ mothers practiced breastfeeding at birth and the rate of EBF was 7 and $0 \%$, at three and six months, respectively. In Western Tanzania the rate of EBF was $58.0 \%$ in previous 24 h [17]. About 96.0 and $18.0 \%$ of mothers EBF at birth and practised EBF up to six months, respectively, in South Africa [18]. In Sudan [19], 64.5 and $9.5 \%$ of mothers practiced EBF at four and for six months, respectively. In Egypt, $95.8 \%$ mothers exclusively breastfed at birth and $9.7 \% \mathrm{EBF}$ for 6 months [20].

In Ethiopia, there is inadequate evidence on exclusive breastfeeding rates in previous $24 \mathrm{~h}$. Considering the high percentage of improper infant feeding practices in Ethiopia, the value of EBF and the objective of Millennium Development Goals (MDGs), the Ethiopian Government adopted the Infant and Young Child Feeding (IYCF) guideline in 2004 [21]. Even though various interventions were introduced at the health facility and at the community levels, there has been no significant change observed regarding EBF in the previous $24 \mathrm{~h}$. This might be due to disorganized efforts, poor data management, and an inability to measure the performance and identify hindering factors through research.

In 2009, in Ethiopia, the EBF rates were 56.7 and $49.0 \%$ for the first four and six months respectively [22]. The 2011 Ethiopian Demographic and Health Survey (EDHS) [23] showed a rate of EBF of $52.0 \%$ during the first six months after birth. Evidence from Southeast Ethiopia [24] showed a 71.3 \% EBF rate. As far as we know, EBF in the previous $24 \mathrm{~h}$ and associated factors (the aim of this study) have not been studied in Azezo District, Northwest Ethiopia. In addition, the presence of more than five high and medium level factories within the district with a high local employment sourced, it is believed to have an influence on the rate of EBF in the previous $24 \mathrm{~h}$. Hence, the aim of this study is to provide important evidence on the EBF status and determinant factors to local administrators, North Gondar Zone Health Department, Amhara Regional Health Bureau and the other researchers interested in breastfeeding.

\section{Methods}

A community based cross-sectional study was conducted in Azezo District, Northwest Ethiopia, from May-June 2014. Azezo District is located $12 \mathrm{~km}$ south of Gondar and about $718 \mathrm{~km}$ to the northwest of Addis Ababa, the capital city of Ethiopia. It has seven Kebeles (local administrations). Based on the EDHS 2005, the District has an estimated population of 54, 434 of which $45 \%$ are males [25]. Azezo District health facilities comprise one health center, three private clinics and five pharmacy centers. Azezo is a trade commercial center, is directly connected to Metema, and has more than six medium level factories, like the Guna shoe factory, Dashen brewery factory and others.

All women having children aged from 0-6 months in Azezo District during the study period were sourced to this study. The sample size was calculated using Epi Info Version20 based on the following assumptions: EBF 
prevalence $(p) 71.3 \%$ [24]; $95 \% \mathrm{CI} \pm 1.96$, precision error (d) $4 \%$ and allowing for a $10 \%$ non-response contingency. We aimed for a final sample size of 540. Unfortunately, the actual number of mothers with infants 0-6 months in the district was only 346, based on the evidence from Health Extension Workers and so we decided to include all mothers having 0-6 month old infants in our study. To contact each mother, we took all the necessary information such as Kebeles (local administrations), house numbers and phone numbers from the Health Extension Workers office.

An structured interviewer administered questionnaire was used to collect data from the study participants. The questionnaire was developed by referring to other studies showing exclusive breastfeeding rates and included the WHO exclusive breastfeeding definition [1, 21-24, 26]. The data collection tool was first prepared in English and translated to Amharic (local language) and back to English to check its consistency. Data on socio-demographic factors, breastfeeding practices, birth intervals, parity, antenatal care visits (ANC), postnatal care (PNC) services, access to information about EBF and place of birth were major components of the questionnaire. It was pretested among mothers having 0-6 month infants in Gondar Town to assure its validity. Gondar town is $12 \mathrm{~km}$ from Azezo District, with similar healthcare setups and a similar population.

Seven, second year nursing students (one per Kebele) were recruited as data collectors. The author provided a 1 day training to the data collectors on the study objectives, data collection procedures and data confidentiality issues.

Ethical clearance was obtained from the Ethical Review Committee of Amhara Regional Health Bureau research and technology transfer core process owner. A supporting letter was obtained from Azezo District administration office. Verbal consent was given by each woman in the study, after explaining study objectives, data collection procedures and data confidentiality issues. Participation was fully voluntary based including the right to withdraw from participation if they feel uncomfortable during the process. To insure data confidentiality, no one other than the investigators had access to the data and data were used only for describing the stated objectives.

Data collectors collected data through face to face interviewing of mothers with infants aged from 0-6 months old. The principal investigators provided supportive supervision to the data collectors. Data were checked daily for completeness and consistency. Data were edited and analyzed using Statistical Package Software for Social Science (SPSS) Version20. Descriptive statistics were used to describe the study participants and the practice of EBF in previous $24 \mathrm{~h}$. Exclusive breastfeeding was calculated by accepting infants below 6 months who were fed only breast milk in the $24 \mathrm{~h}$ preceding the survey as numerator, and the total number of infants within the same age group (0-6 months) as denominator. Binary logistic regression analysis was made to each independent variable to EBF in previous $24 \mathrm{~h}$. Finally, multivariable logistic regression was computed on independent variables tested by binary regression analysis to determine independent predictors of outcome variable. Odds ratio at $\mathrm{CI}$ and $p$-value $<0.05$ were used to describe significance and strength of association between the study and outcome variables.

\section{Results}

Sociodemographic characteristics of mother-child pairs

From the total 346 mothers with infants aged 0 to 6 months, 332 responded to the questionnaire (response rate of $96 \%)$. More than half (63.0\%) of mothers were aged less than 30 years. The majority of mothers, 242 (73.0 \%) were Orthodox Christian followers. Most of the mothers $(87.0 \%)$ were Amhara in ethnicity. Nearly half $(48.2 \%)$ the mothers did not attend formal education (from grade 1 to higher education). Most mothers were married $(72.0 \%)$ and $67.0 \%$ were unemployed. Less than half $(41.0 \%)$ of them earned $\leq 1000$ Ethiopian birr (US \$47.62) monthly (Table 1).

Table 1 Sociodemographic variables of mothers and infants in Azezo District, Northwest Ethiopia, 2014

\begin{tabular}{|c|c|c|c|}
\hline Variables & Category & Frequency & Percent (\%) \\
\hline Age in year & $\begin{array}{l}\leq 30 \\
>30\end{array}$ & $\begin{array}{l}180 \\
152\end{array}$ & $\begin{array}{l}63.0 \\
37.0\end{array}$ \\
\hline Religion & $\begin{array}{l}\text { Orthodox } \\
\text { Muslim }\end{array}$ & $\begin{array}{l}242 \\
90\end{array}$ & $\begin{array}{l}73.0 \\
27.0\end{array}$ \\
\hline Ethnicity & $\begin{array}{l}\text { Amhara } \\
\text { Tigre } \\
\text { Oromo }\end{array}$ & $\begin{array}{l}289 \\
33 \\
10\end{array}$ & $\begin{array}{l}87.0 \\
10.0 \\
3.0\end{array}$ \\
\hline $\begin{array}{l}\text { Education } \\
\text { status }\end{array}$ & $\begin{array}{l}\text { Informal education }{ }^{a} \\
\text { Formal education }\end{array}$ & $\begin{array}{l}160 \\
172\end{array}$ & $\begin{array}{l}48.2 \\
51.8\end{array}$ \\
\hline Marital status & $\begin{array}{l}\text { Single } \\
\text { Married }\end{array}$ & $\begin{array}{l}92 \\
240\end{array}$ & $\begin{array}{l}28.0 \\
72.0\end{array}$ \\
\hline Occupation & $\begin{array}{l}\text { Housewife } \\
\text { Merchant } \\
\text { Governmental employee } \\
\text { Non-governmental } \\
\text { employee } \\
\text { Daily labourer }\end{array}$ & $\begin{array}{l}111 \\
90 \\
83 \\
26 \\
22\end{array}$ & $\begin{array}{l}33.4 \\
27.0 \\
25.0 \\
8.0 \\
6.6\end{array}$ \\
\hline Sex of infant & $\begin{array}{l}\text { Male } \\
\text { Female }\end{array}$ & $\begin{array}{l}133 \\
199\end{array}$ & $\begin{array}{l}40.0 \\
60.0\end{array}$ \\
\hline Age of infant & $\begin{array}{l}\leq 3 \text { months } \\
3-6 \text { months }\end{array}$ & $\begin{array}{l}151 \\
181\end{array}$ & $\begin{array}{l}45.5 \\
54.5\end{array}$ \\
\hline $\begin{array}{l}\text { Monthly } \\
\text { income }\end{array}$ & $\begin{array}{l}\leq 1000 \text { birr } \\
>1000 \text { birr }\end{array}$ & $\begin{array}{l}136 \\
196\end{array}$ & $\begin{array}{l}41.0 \\
59.0\end{array}$ \\
\hline
\end{tabular}

anformal education: type of education where there is no regular class, it is a form of mass education to enable adults to read and write 


\section{Obstetric care, prenatal and postnatal care and access to information}

More than half (56\%) of studied mothers had 1-2 birth intervals respectively. A large number, 300 (90.0\%) of mothers attended antenatal visits and three-quarters received advice on EBF there. Nearly half (49.0\%) of the mothers received postnatal care and counselling. Only $70(15.0 \%)$ of the interviewed mothers practiced prelacteal feeding, the reasons given were; being busy, less knowledge on EBF and an assumption that prelacteal feeding is more important to infants than EBF.

The number of exclusive breastfeeds in the previous $24 \mathrm{~h}$ was 6.5. Over one third of mothers (36.0\%) reported accessing the available information on EBF and their major information sources were health facilities (78.8\%). Almost three-quarters (76.0 \%) of mothers delivered vaginally. The rates of EBF were $79 \%$ and mixed breastfeeding in Azezo District was 99 \% (Table 2). Exclusive breastfeeding was inversely proportional with the infants' age. Exclusive breastfeeding rates were 79, 62.0,

Table 2 Obstetric care, antenatal/postnatal care and information on EBF (exclusive breastfeeding) practices in Azezo District, Northwest Ethiopia, 2014

\begin{tabular}{|c|c|c|c|}
\hline Variables & Category & Frequency & Percent (\%) \\
\hline Parity of mothers & $\begin{array}{l}1-2 \\
>3+\end{array}$ & $\begin{array}{l}142 \\
190\end{array}$ & $\begin{array}{l}75.0 \\
25.0\end{array}$ \\
\hline Birth interval (year) & $\begin{array}{l}1-2 \\
3-4\end{array}$ & $\begin{array}{l}185 \\
147\end{array}$ & $\begin{array}{l}56.0 \\
44.0\end{array}$ \\
\hline Antenatal care received & $\begin{array}{l}\text { Yes } \\
\text { No }\end{array}$ & $\begin{array}{l}300 \\
32\end{array}$ & $\begin{array}{l}90.0 \\
10.0\end{array}$ \\
\hline Number of antenatal visits & $\begin{array}{l}1 \\
2-3 \\
=4\end{array}$ & $\begin{array}{l}90 \\
123 \\
87\end{array}$ & $\begin{array}{l}30.0 \\
41.0 \\
29.0\end{array}$ \\
\hline $\begin{array}{l}\text { Received information on } \\
\text { EBF during antenatal care }\end{array}$ & $\begin{array}{l}\text { Yes } \\
\text { No }\end{array}$ & $\begin{array}{l}228 \\
72\end{array}$ & $\begin{array}{l}76.0 \\
24.0\end{array}$ \\
\hline Postnatal counselling & $\begin{array}{l}\text { Yes } \\
\text { No }\end{array}$ & $\begin{array}{l}162 \\
170\end{array}$ & $\begin{array}{l}49.0 \\
51.0\end{array}$ \\
\hline Prelacteal feeding: & $\begin{array}{l}\text { Yes } \\
\text { No }\end{array}$ & $\begin{array}{l}70 \\
262\end{array}$ & $\begin{array}{l}15.0 \\
79.0\end{array}$ \\
\hline $\begin{array}{l}\text { Information availability on } \\
\text { EBF }\end{array}$ & $\begin{array}{l}\text { Yes } \\
\text { No }\end{array}$ & $\begin{array}{l}120 \\
212\end{array}$ & $\begin{array}{l}36.0 \\
64.0\end{array}$ \\
\hline Information source on EBF & $\begin{array}{l}\text { Health facility } \\
\text { Non health } \\
\text { facility }\end{array}$ & $\begin{array}{l}258 \\
74\end{array}$ & $\begin{array}{l}78.8 \\
22.2\end{array}$ \\
\hline Place of delivery & $\begin{array}{l}\text { Home } \\
\text { Public facility } \\
\text { Private facility }\end{array}$ & $\begin{array}{l}70 \\
195 \\
67\end{array}$ & $\begin{array}{l}21.0 \\
59.0 \\
20.0\end{array}$ \\
\hline Type of delivery & $\begin{array}{l}\text { Normal/vaginal } \\
\text { Caesarean }\end{array}$ & $\begin{array}{l}251 \\
81\end{array}$ & $\begin{array}{l}76.0 \\
24.0\end{array}$ \\
\hline $\begin{array}{l}\text { Initiated breastfeeding in } \\
\text { first hour }\end{array}$ & $\begin{array}{l}\text { Yes } \\
\text { No }\end{array}$ & $\begin{array}{l}262 \\
66\end{array}$ & $\begin{array}{l}79.0 \\
21.0\end{array}$ \\
\hline Breastfeeding practices & $\begin{array}{l}\text { Yes } \\
\text { No }\end{array}$ & $\begin{array}{l}329 \\
3\end{array}$ & $\begin{array}{l}99.0 \\
1.0\end{array}$ \\
\hline
\end{tabular}

52, 43.0 and $29 \%$ at $\leq$ second, third, fourth, fifth and 6th months of infants' age, respectively.

\section{Factors affecting exclusive breastfeeding practices}

The bivariable and multivariable logistic regression analysis revealed that maternal related (age, education status, employment status, monthly income, place of delivery, antenatal visit), infants' age, information on EBF, prelacteal feeding practices and availability of resources were all independent predictors to EBF practices in previous $24 \mathrm{~h}$ (Table 3 ).

Mothers whose age was $\geq 30$ years were more likely to exclusively breastfed infants compared with mothers < 30 years old (OR 2.07; $95 \%$ CI 1.17, 3.68). Infants $\leq$ 3 months old were more likely to be exclusively breastfed than infants within 3-6 months age range (OR 2.12; $95 \%$ CI 1.17, 3.85). Mothers with informal education and earning a monthly income of $\leq 1000$ Ethiopia birr (US \$47.62) were 54.0 and $77.0 \%$ less likely to practice EBF than their counter parts, respectively. Unemployed mothers were more likely to practice better EBF than employed mothers (OR 1.88; 95 \% CI 1.05, 3.33). Mothers who delivered at healthcare facility and those who had antenatal care exclusively breastfed their infants more than mothers who delivered at home and those who did not have antenatal care (OR 2.45; 95 \% CI 1.31, 4.59 and OR 2.92; $95 \%$ CI 1.27, 6.64), respectively. Infants from mothers who did not practice prelacteal feeding were more likely to be EBF (OR 2.24; 95 \% CI 1.19, 4.20) (Table 3).

\section{Discussion}

Exclusive breastfeeding is very important and an economical way of feeding babies worldwide. This study revealed a $99.0 \%$ initiation rate of breastfeeding which is similar to studies conducted in India [11], Ghana [14], Egypt [20], Uganda [16], South Africa [18] and Ethiopia $[22,24]$ where other breastfeeding practices were 100, 99.7, 95.8, 99.0, 96.0 and 96.0-98.0\% respectively. Possible reasons for this high rate could be community acceptance and involvement, government concern, health facilities participation and the increased efforts to achieve the 2015 Millennium Development Goals (MDGs), in relation to child and maternal health since it is the world's primary agenda. However, this finding is higher than the study findings from Brazil [9] where non-exclusive breastfeeding in previous $24 \mathrm{~h}$ was $72.5 \%$. The probable reasons to this discrepancy could be a variation in study period and the increased effort made in Ethiopia to achieve MDGs as Ethiopia achieved the maternal and child health component of MDGs before 2015.

This study also revealed a $79 \%$ EBF rate in previous $24 \mathrm{~h}$, which is in line with study findings from Jordan 
Table 3 Factors affecting exclusive breastfeeding among mothers in Azezo District, Northwest Ethiopia, $2014(n=332)$

\begin{tabular}{|c|c|c|c|c|}
\hline \multirow[t]{2}{*}{ Variables } & \multicolumn{2}{|c|}{ Exclusive breastfeeding } & \multirow{2}{*}{$\begin{array}{l}\text { Crude Odds } \\
\text { Ratio }(95 \% \text { Cl) }\end{array}$} & \multirow{2}{*}{$\begin{array}{l}\text { Adjusted Odds } \\
\text { Ratio }(95 \% \mathrm{Cl})\end{array}$} \\
\hline & Yes (\%) & No (\%) & & \\
\hline \multicolumn{5}{|l|}{ Mothers' age (years) } \\
\hline $\begin{array}{l}<30 \\
\geq 30\end{array}$ & $\begin{array}{l}110(33.0) \\
152(46.0)\end{array}$ & $\begin{array}{l}42(12.6) \\
28(8.4)\end{array}$ & $\begin{array}{l}1 \\
2.07(1.17,3.68)\end{array}$ & $\begin{array}{l}1 \\
1.75(1.14,3.42)\end{array}$ \\
\hline \multicolumn{5}{|l|}{ Infants' age (months) } \\
\hline $\begin{array}{l}\leq 3 \\
3-6\end{array}$ & $\begin{array}{l}129(39.0) \\
133(40.0)\end{array}$ & $\begin{array}{l}22(6.6) \\
48(14.4)\end{array}$ & $\begin{array}{l}2.12(1.17,3.85) \\
1\end{array}$ & $\begin{array}{l}1.86(1.15,3.26) \\
1\end{array}$ \\
\hline \multicolumn{5}{|l|}{ Religion } \\
\hline $\begin{array}{l}\text { Orthodox } \\
\text { Muslim }\end{array}$ & $\begin{array}{l}194(58.4) \\
69(21.0)\end{array}$ & $\begin{array}{l}48(14.6) \\
21(6.0)\end{array}$ & $\begin{array}{l}1.23(0.66,2.28) \\
1\end{array}$ & $\begin{array}{l}0.78(0.45,1.79) \\
1\end{array}$ \\
\hline \multicolumn{5}{|l|}{ Educational status } \\
\hline $\begin{array}{l}\text { Informal education } \\
\text { Formal education }\end{array}$ & $\begin{array}{l}118(35.5) \\
144(43.4)\end{array}$ & $\begin{array}{l}42(12.7) \\
28(8.4)\end{array}$ & $\begin{array}{l}0.55(0.31,0.97) \\
1\end{array}$ & $\begin{array}{l}0.49(0.28,0.89) \\
1\end{array}$ \\
\hline \multicolumn{5}{|l|}{ Marital status } \\
\hline $\begin{array}{l}\text { Single } \\
\text { Married }\end{array}$ & $\begin{array}{l}60(18.0) \\
202(61.0)\end{array}$ & $\begin{array}{l}32(9.6) \\
38(11.4)\end{array}$ & $\begin{array}{l}0.35(0.20,0.63) \\
1\end{array}$ & $\begin{array}{l}0.32(0.39,1.52) \\
1\end{array}$ \\
\hline \multicolumn{5}{|l|}{ Employment status } \\
\hline $\begin{array}{l}\text { Employed } \\
\text { Unemployed }\end{array}$ & $\begin{array}{l}78(23.5) \\
184(55.4)\end{array}$ & $\begin{array}{l}31(9.1) \\
39(12.0)\end{array}$ & $\begin{array}{l}1 \\
1.88(1.05,3.33)\end{array}$ & $\begin{array}{l}1 \\
1.62(1.03,2.95)\end{array}$ \\
\hline \multicolumn{5}{|l|}{ Infants' sex } \\
\hline $\begin{array}{l}\text { Male } \\
\text { Female }\end{array}$ & $\begin{array}{l}95(28.6) \\
167(50.3)\end{array}$ & $\begin{array}{l}38(11.5) \\
32(9.6)\end{array}$ & $\begin{array}{l}0.48(0.27,0.84) \\
1\end{array}$ & $\begin{array}{l}0.52(0.32,1.73) \\
1\end{array}$ \\
\hline \multicolumn{5}{|l|}{ Monthly income(birr) } \\
\hline $\begin{array}{l}\leq 1000 \\
>1000\end{array}$ & $\begin{array}{l}90(27.0) \\
172(52.0)\end{array}$ & $\begin{array}{l}46(14.0) \\
24(7.0)\end{array}$ & $\begin{array}{l}0.25(0.15,0.49) \\
1\end{array}$ & $\begin{array}{l}0.23[0.13,0.44] \\
1\end{array}$ \\
\hline \multicolumn{5}{|l|}{ Parity of mothers } \\
\hline $\begin{array}{l}1-2 \\
3 \text { and above }\end{array}$ & $\begin{array}{l}115(35.0) \\
147(44.0)\end{array}$ & $\begin{array}{l}27(8.0) \\
43(13.0)\end{array}$ & $\begin{array}{l}1.25(0.7,2.21) \\
1\end{array}$ & $\begin{array}{l}1.18(0.56,1.99) \\
1\end{array}$ \\
\hline \multicolumn{5}{|l|}{ Birth interval (year) } \\
\hline $\begin{array}{l}1-2 \\
3-4\end{array}$ & $\begin{array}{l}140(42.0) \\
122(37.0)\end{array}$ & $\begin{array}{l}45(13.5) \\
25(7.5)\end{array}$ & $\begin{array}{l}0.64(0.36,1.14) \\
1\end{array}$ & $\begin{array}{l}0.58(0.31,1.12) \\
1\end{array}$ \\
\hline \multicolumn{5}{|l|}{ Type of delivery } \\
\hline $\begin{array}{l}\text { Vaginal } \\
\text { Caesarean }\end{array}$ & $\begin{array}{l}203(61.0) \\
59(18.0)\end{array}$ & $\begin{array}{l}48(14.4) \\
22(6.6)\end{array}$ & $\begin{array}{l}1.58[0.85,2.93] \\
1\end{array}$ & $\begin{array}{l}1.26(0.78,2.65) \\
1\end{array}$ \\
\hline \multicolumn{5}{|l|}{ Place of birth } \\
\hline $\begin{array}{l}\text { Home } \\
\text { Healthcare facility }\end{array}$ & $\begin{array}{l}46(14.0) \\
216(65.0)\end{array}$ & $\begin{array}{l}24(7.0) \\
46(14.0)\end{array}$ & $\begin{array}{l}1 \\
2.45(1.31,4.59)\end{array}$ & $\begin{array}{l}1 \\
2.18(1.22,4.35)\end{array}$ \\
\hline \multicolumn{5}{|l|}{ Antenatal care } \\
\hline $\begin{array}{l}\text { Yes } \\
\text { No }\end{array}$ & $\begin{array}{l}243(73.0) \\
19(6.0)\end{array}$ & $\begin{array}{l}57(17.0) \\
13(4.0)\end{array}$ & $\begin{array}{l}2.92(1.27,6.64) \\
1\end{array}$ & $\begin{array}{l}2.24(1.18,5.76) \\
1\end{array}$ \\
\hline \multicolumn{5}{|c|}{ Received information on EBF during pregnancy } \\
\hline $\begin{array}{l}\text { Yes } \\
\text { No }\end{array}$ & $\begin{array}{l}206(69.0) \\
56(19.0)\end{array}$ & $\begin{array}{l}22(7.0) \\
16(5.0)\end{array}$ & $\begin{array}{l}2.68(1.24,5.74) \\
1\end{array}$ & $\begin{array}{l}1.98(1.18,5.20) \\
1\end{array}$ \\
\hline \multicolumn{5}{|l|}{ Postnatal care: } \\
\hline $\begin{array}{l}\text { Yes } \\
\text { No }\end{array}$ & $\begin{array}{l}137(41.0) \\
125(38.0)\end{array}$ & $\begin{array}{l}25(7.5) \\
45(13.5)\end{array}$ & $\begin{array}{l}1.97(1.11,3.53) \\
1\end{array}$ & $\begin{array}{l}1.62(1.09,3.21) \\
1\end{array}$ \\
\hline \multicolumn{5}{|l|}{ Prelacteal feeding } \\
\hline $\begin{array}{l}\text { Yes } \\
\text { No }\end{array}$ & $\begin{array}{l}47(14.0) \\
215(65.0)\end{array}$ & $\begin{array}{l}23(7.0) \\
47(14.0)\end{array}$ & $\begin{array}{l}1 \\
2.24(1.19,4.20)\end{array}$ & $\begin{array}{l}1 \\
1.92(1.12,3.85)\end{array}$ \\
\hline \multicolumn{5}{|l|}{ Access to information } \\
\hline $\begin{array}{l}\text { Yes } \\
\text { No }\end{array}$ & $\begin{array}{l}212(64.0) \\
50(15.0)\end{array}$ & $\begin{array}{l}46(14.0) \\
24(7.0)\end{array}$ & $\begin{array}{l}2.21(1.19,4.12) \\
1\end{array}$ & $\begin{array}{l}2.16(1.16,4.06) \\
1\end{array}$ \\
\hline
\end{tabular}


[27], South Africa [14], Ghana [7], Ethiopia [24, 28], where EBF in previous $24 \mathrm{~h}$ were $70,76.5,79,71.3$ and $81 \%$, respectively. On the other hand, this finding of $79 \%$ in Azezo District was less when compared with study findings from India [11], where the EBF practice among infants at 3 months was 97 and $62 \%$ at 6 months. The reasons for this variation between Ethiopia and India could be differences in the level of community awareness, access to information on EBF, maternal education, quality of antenatal care, health professionals' commitment, access to health facility, culture, monthly income and provision of postnatal care .

The rate of EBF in previous $24 \mathrm{~h}$ is higher when compared to study findings from the Al Hassa-Soudi Arabia [10]: 24.4 \%, Brazil [4, 9]:39 and $43.7 \%$, Uganda [16]:7 \%, Egypt [20]: 9.7 \%, Tanzania [17]: 58 \%, Ghana [14]: $51.6 \%$ and South Africa [18]:18 \%. Possible justifications for this variation could be the study period and increased Ethiopian Government efforts to improve maternal and child health through a community based Health Extension Program. It is also due to community involvement, increased number of health facilities/health professionals every year, advice given at antenatal and postnatal care clinics $(90 \%$ mothers visited the antenatal clinic) and the high use of delivering at a healthcare facility (79 \%) (Table 2).

It is also higher compared with previous studies conducted in Ethiopia: 56.7 and $49 \%$ at four and 6 months in Oromia Region [22] and $52 \%$ national EDHS 2011 survey [23]. Logical reasons to this variation are differences in study period and community awareness $(76 \%$ received advice at antenatal clinics, $90 \%$ visited antenatal clinics and $79 \%$ delivered at the healthcare facility).

The logistic regression analysis showed that older mothers ( $\geq 30$ years) practiced more EBF (OR 2.07; $95 \%$ CI $1.17,3.68)$ than mothers $<30$ years of age. The reason could be that as the maternal age increased, infant management experiences will also be increased. Younger mothers also thought their breast size and beauty will be affected if they practiced EBF for a longer time, hence they usually give the infant rearing responsibilities to servants and started supplementary feeding early.

Younger infants $\leq 3$ months age were (OR 2.12; $95 \%$ CI $1.17,3.85)$ more to be exclusively breastfed than infants aged between 4-6 months. Several studies $[9,12,14,16-18,22-24,28]$ also strengthen this correlation, where infants' EBF and age are inversely related. The logical explanation could be the commitment of mothers to either home or office works and the introduction of supplementary feedings. Mothers with no and informal education were $45 \%$ less likely to exclusively breastfeed their infants compared with their counter parts (Table 3). Research findings $[4,7,9,12,22,23,29]$ supported this, where lower maternal education was predictor to lower EBF in previous $24 \mathrm{~h}$. It is true that non educated mothers do not have the scientific knowledge and have difficulty understanding the written messages and antenatal care advice on EBF. Hence, they will introduce supplementary feeding to their infants early by assuming it is good compared with the formally educated mothers.

In the case of employment status, unemployed mothers practiced relatively better EBF than their counter parts (OR 1.88; 95 \% CI 1.05, 3.33), which is in agreement with study findings from Saudi Arabia [10], Brazil [4] and Ethiopia [22-24, 28]. Employed mothers may be relatively overloaded with their office and home activities so may have limited contact time with infants. Low family income can hinder EBF practices in the previous $24 \mathrm{~h}$; $75 \%$ lower than EBF in mothers with higher income (Table 3). It is also supported by evidences from Brazil [4] and Ethiopia [22, 28].

Justification to this could be that mothers with a low family income spend most of their time working to gain additional money to feed their families, and so may start early supplementary feeding.

The exclusive breastfeeding practice of mothers who delivered at healthcare facilities was double compared with mothers who delivered at home (OR 2.45; 95 \% CI $1.31,4.59)$. It is supported with study findings from Tanzania [17], Ghana [14] and Ethiopia [28, 29]. Logical reasons could be the impact of information on EBF that they received from the healthcare facilities. However, this finding differed with findings from Canada [12] where mothers delivered at home were more likely to remain exclusively breastfeeding for 6 months.

Frequent antenatal and postnatal care visits showed significant association with EBF in previous $24 \mathrm{~h}$ (Table 3), which was also true at different studies $[13,20,29,30]$. Possible justification could be the increased knowledge and attitudinal changes due to the information provided by the antenatal care clinics on infant feeding and the nutritional values of breast milk. Similarly, mothers who did not practice prelacteal feeding were twice as likely to EBF in previous $24 \mathrm{~h}$ than the respective groups. Prelacteal feeding will prevent the infants to take an adequate amount of breast milk with the appropriate frequency. This will result in poor EBF in previous $24 \mathrm{~h}$ and different outcomes in infants' health status. Infants who are never received any supplements are most likely to be exclusively fed on maternal milk $[3,10,16,24]$.

\section{Conclusions}

The incidence of exclusive breastfeeding and other breastfeeding practices of mothers with 0-6 month old infants in Azezo District are high compared with previous study 
findings. The number of exclusive breastfeeds in $24 \mathrm{~h}$ is below the WHO infant and young child feeding recommendation. Maternal factors (age, education, income, employment, antenatal care service, no prelacteal feeding), infants' age, place of birth and access to information were determinants to EBF practices in previous $24 \mathrm{~h}$. Improving women knowledge, income, access to information, nutritional counselling, quality of antenatal and postnatal care, place of birth and avoidance of prelacteal feeding are important to improve EBF in previous $24 \mathrm{~h}$.

\begin{abstract}
Abbreviations
AOR, adjusted odds ratio; ANC, antenatal care: $\mathrm{Cl}$, confidence interval; $\mathrm{COR}$, crude odds ratio; EDHS, Ethiopian Demographic and Health Survey; EBF, exclusive breastfeeding; HIV, Human Immune Deficiency Virus; IYCF, Infant and Young Child Feeding; MDGs, Millennium Development Goals; PNC, postnatal care; SPSS, Statistical Packages for Social Sciences; WHO, World Health Organization
\end{abstract}

\section{Acknowledgements}

I would like to express my gratitude to Amhara Regional Health Bureau for giving the ethical clearance. I would also like to thank Azezo District administrative office, health departments, health extension workers and the mothers in this study, for their unreserved support and cooperation.

\section{Competing interests}

The author declared that there are no any competing interests.

Received: 18 August 2015 Accepted: 25 July 2016

Published online: 02 August 2016

\section{References}

1. Qasem W, Fenton T, Friel J. Age of introduction of first complementary feeding for infants: a systematic review. BMC Pediatr. 2015;15:107.

2. World Health Organization. Infant and young child feeding (IYCF) model chapter for textbooks for medical students and allied health professionals. Switzerland: WHO; 2009.

3. Declercq E, Labbok MH, Sakala C, O'Hara MA. Hospital practices and Women's likelihood of fulfilling their intention to exclusively breastfeed. Am J Public Health. 2009;99(5):929-35.

4. Mascarenhas ML, Albernaz EP, da Silva MB, da Silveira RB. Prevalence of exclusive breastfeeding and its determiners in the first 3 months of life in the South of Brazil. J Paediatr. 2006;82(4):289-94.

5. Gartner LM, Morton J, Lawrence RA, et al. Breastfeeding and the use of human milk. Pediatrics. 2005;115(2):496-506.

6. Horta BL, Bahl R, Martines JC, et al. Evidence on the Long Term Effects of Breastfeeding. Systematic Reviews and Meta Analyses. Geneva: WHO; 2007.

7. World Health Organization. Global Strategy for Infant and Young Child Feeding. Geneva: World Health Organization; 2003.

8. United Nations Children's Fund (UNICEF). The State of the World's Children 2008: Child Survival. United Nations Children's Fund, New York, 2007

9. Nascimento MB, Ries MA, Franco SC, Issler H, Ferraro AA, Grisi SJ. Exclusive Breastfeeding in Southern Brazil: Prevalence and Associated Factors. Breastfeed Med. 2010;5(2):79-85.

10. El-Gilany AH, Shady E, Helal R. Exclusive Breastfeeding in Al-Hassa Saudi Arabia. Breastfeed Med. 2011:6:4,209-213.

11. Chudasama RK, Amin CD, Parikh YN. Prevalence of exclusive breastfeeding and its determinants in first 6 months of life: A prospective study. Online Health Allied Sci. 2009;8:1.

12. Al-Sahab B, Lanes A, Feldman M, Tamim H. Prevalence and predictors of 6month exclusive breastfeeding among Canadian women: a national survey. BMC Pediatr. 2010;10:20.

13. Bland RM, Little KE, Coovadia HM, Coutsoudis A, Rollinse NC, Newell ML. Intervention to promote exclusive breast-feeding for the first 6 months of life in a high HIV prevalence area. J Acquir Immune Defic Syndr. 2008;22(7): 883-91.

14. Aidam BA, Perez-Escamilla R, Lartey A, Aidam J. Factors associated with exclusive breastfeeding in Ghana. Eur J Clin Nutr. 2005;59(6):789-96.
15. Poggensee G, Schulze K, Moneta I, Mbezi P, Baryomunsi C, Harms G. Infant feeding practices in western Tanzania and Uganda: implications for infant feeding recommendations for HIV-infected mothers. Trop Med Int Health. 2004:9(4):477-85.

16. Engebretsen IMS, Wamani H, Charles KC, Nulu SN, Tumwine J, Tylleskär T. Low adherence to exclusive breastfeeding in Eastern Uganda: A community-based cross-sectional study comparing dietary recall since birth with 24-h recall. BMC Pediatr. 2007;7:10.

17. Nkala TE, Msuya SE. Prevalence and predictors of exclusive breastfeeding among women in Kigoma region Western Tanzania: a community based cross sectional study. Int Breastfeed J. 2011;6:17.

18. Ghuman MR, Saloojee H, Morris G. Infant feeding practices in a high HIV prevalence rural district of KwaZulu-Natal, South Africa. South Africa J Clin Nutrit. 2009;22(2):74-9.

19. Haroun HM, Mahfouz MS, Ibrahim BY. Breast feeding indicators in Sudan: a case study of Wad Medani town. Sudanese J Pub Health. 2008;3(2):81-90.

20. Al Ghwass MM, Ahmed D. Prevalence and Predictors of 6-Month Exclusive Breast feeding in a Rural Area in Egypt. Breastfeed Med. 2011;6:4.

21. Federal Ministry of Health: National strategy for Infant and Young Child Feeding (IYCF). EFMH, Family Health Department; 2004. https://extranet.who. int/...ETH\%202004\%20National\%20Strategy\%20for\%20Infant.

22. Alemayehu T, Haidar J, Habte D. Determinants of exclusive breastfeeding practices in Ethiopia. Ethiop J Health Dev. 2009;23(1):12-8.

23. Central Statistical Agency. Ethiopia Demographic and Health Survey Report. Addis Ababa, Ethiopia, 2011. https://dhsprogram.com/pubs/pdf/FR255/ FR255.pdf.

24. Setegn T, Belachew T, Gerbaba M, Deribe K, Deribew A, Biadgilign S. Factors associated with exclusive breastfeeding practices among mothers in Goba district, south east Ethiopia: a cross-sectional study. Int Breastfeed J. 2012;7:17.

25. Ethiopian Central Statistical Agency of Ethiopia. The 2007 National Statistics. http://ecastats.uneca.org/aicmd/Portals/0/Cen2007_firstdraft.pdf. Accessed 27 July 2016.

26. World Health Organization. Global strategy for infant and young child feeding. The optimal duration of exclusive breastfeeding. Geneva: WHO; 2001.

27. Oweis A, Tayem A, Froelicher ES. Breastfeeding practices among Jordanian women. Int J Nurs Pract. 2009;15(1):32-40.

28. Central Statistical Agency [Ethiopia] And ORC Macro. Ethiopia Demographic and Health Survey (EDHS) 2005. Ethiopia and Calverton, Maryland, USA: Central Statistical Agency and ORC Macro; 2006; 2005.

29. Setegn T, Mulusew GM, Belachew T. Determinants of timely initiation of breastfeeding among mothers in Goba Woreda, South East Ethiopia: A cross sectional study. BMC Public Health. 2011;11:217.

30. Su LL, Chong YS, Chan YH, Chan YS, Fok D, Tun KT, Ng FSP, Rauff M. Antenatal education and postnatal support strategies for improving rates of exclusive breast feeding: randomized controlled trial. Br Med J. 2007; 335(7620):396. bmi.com.

Submit your next manuscript to BioMed Central and we will help you at every step:

- We accept pre-submission inquiries

- Our selector tool helps you to find the most relevant journal

- We provide round the clock customer support

- Convenient online submission

- Thorough peer review

- Inclusion in PubMed and all major indexing services

- Maximum visibility for your research

Submit your manuscript at www.biomedcentral.com/submit
Ciomed Central 